A „Talajok Nemzetközi Éve” alkalmából az Agrokémia és Talajtan 2015. évi 64. kötet 2. száma angol nyelvü lesz, ezért a vitacikkekre reagálni a 2016. évi 65. kötet 1. számban lesz lehetőség.

\title{
VITAROVAT
}

\section{Javaslat a hazai genetikai talajszintek leírásának a FAO irányelveknek megfelelő módosítására}

\author{
FUCHS Márta és MICHÉLI Erika
}

Szent István Egyetem, Talajtani és Agrokémiai Tanszék, Gödöllő

\section{Bevezetés}

A talajok a talajképző tényezők és -folyamatok együttes hatására képződnek és tagolódnak szintekre. A genetikai talajszintek jellemzése és meghatározása a terepi körülmények között leírható morfológiai, fizikai és kémiai talajtulajdonságok alapján történik és alapul szolgál a talajképződés folyamatának megértéséhez, a mintavételi mélységek meghatározáshoz, és a talajok osztályozásához. A diagnosztikai szemléletủ talajosztályozási rendszerek is a genetikai szintek felismerésén alapulnak, azonban azokat további, főként a fejlődési stádiumokat számszerüen kifejező, szigorúbb morfológiai és méréseken alapuló tulajdonságokhoz köti.

A hazai és nemzetközi adatbázisokhoz tartozó helyszíni leírások és laboratóriumi mérési eredmények adatai a genetikai szintekhez vagy esetenként határozott mintavételi mélységekhez tartozóan kerülnek tárolásra. A genetikai szintek azonos értelmezése mind a hazai szakemberek között, mind a nemzetközi fórumokon fontos és elengedhetetlen.

A jelenlegi hivatalos hazai nevezéktan a SzABOLCS (1966) valamint JASSÓ és munkatársai $(1987$; 1989) által készített, több kiadásban megjelent munkákon alapszik. A két útmutató elkészülése óta azonban jelentősen bővültek a talajokról szerzett ismereteink, és módosultak a nemzetközi helyszíni leírások útmutatói is.

Az utóbbi évtizedek világossá tették a környezeti, társadalmi és gazdasági változások globális jellegét, és a harmonizált talajinformáció szükségességét (European Union, 2007). Az Európai Unió felé az INSPIRE (Infrastructure for Spatial Information in Europe) direktívában is megfogalmazott (INSPIRE THEMATIC WORKING GROUP SOIL, 2011) adatszolgáltatási kötelezettségeink, a nemzetközi programokban (GSSoil, eSOTER) és fórumokon való részvételünk egyaránt sürgetik, hogy a hazai talajtani nevezéktan alkalmazkodjék a kor elvárásaihoz. Az Európai Talajadat Központ (ESDAC, European Soil Data Center), az INSPIRE és a Nemzetközi Talajtani Unió (IUSS, International Union of Soils Sciences) egyaránt

Postai cím: FUCHS MÁRTA, Szent István Egyetem, Talajtani és Agrokémiai Tanszék, 2103 Gödöllö, Páter K. u. 1. E-mail: fuchs.marta@mkk.szie.hu 
a FAO koordinálásban készült „Útmutató a talajok leírásához” című kiadványt ajánlja az egységes nevezéktan alapjául (FAO, 2006). Az útmutató nem csak a mezögazdasági, hanem valamennyi talaj egységes leírását szolgálja. Az erdős területeken történt sikeres alkalmazását a BioSoil project bizonyította, amely során Európa szerte, így hazánkban is, az erdész szakemberek egységesen dokumentálták talajaikat a FAO útmutató alapján (HIEDERER et al, 2011).

A FAO útmutató nevezéktana néhány kivétellel megegyezik az Egyesült Államokban, és több fejlődő országban alkalmazott „Talajfelvételezési útmutató”-ban (SOIL SURVEY Division STAFF, 1993; SCHOENEBERGER et al., 2012) foglaltakkal.

A fentiek alapján javaslatot teszünk a hazai genetikai szintek helyszíni leírásának a nemzetközi ajánlásokhoz alkalmazkodó megújítására, amely a hazai talajosztályozás megújításához készülö útmutatót is elökészíti.

\section{Anyag és módszer}

Javaslat a nemzetközi nevezéktanhoz alkalmazkodó hazai genetikai szintek leirására és jelölésre

Dolgozatunkban a FAO koordinálásban készült, „Útmutató a talajok leírásához” címü kiadványban (FAO, 2006) közölt nevezéktannal harmonizált, de a hazai viszonyokra adaptált - a nem jellemző tulajdonságok törlésével rövidített, ill. szükség szerint kiegészített - genetikai talajszint leírásokat és jelöléseket mutatjuk be. A FAO definícióktól való eltéréseket, kiegészítéseket dőlt betűvel jeleztük.

A javaslat első megközelítését az OTKA-46513 számú pályázat zárójelentésében mutattuk be (MiCHÉLI et al., 2009). A jelenlegi, és a javasolt nomenklatúra összehasonlítása a meglévő útmutatók (SZABOLCS, 1966; JASSÓ, 1989) és kiadványok (STEFANOVITS, 1972) alapján történt.

\section{A fö genetikai talajszintek (master horizons)}

A genetikai talajszintek talajképző tényezők és folyamatok együttes hatására képződnek és különülnek el a talajszelvényben, közöttük ún. „genetikai kapcsolat” van.

A genetikai talajszintek elkülönítésére nyomtatott nagy betűket használunk, a következők szerint:

Szerves talajszintek

H-szint - le nem bomlott, vagy csak részlegesen lebomlott nagy mennyiségü szerves anyagot tartalmazó, huzamos ideig víztelített felszíni vagy felszín alatti eltemetett talajszint.

A lecsapolt, de még mindig jelentős lebomlatlan, ill. részlegesen lebomlott szerves anyagot tartalmazó talajszinteket szintén $\mathrm{H}$-szintnek nevezzük.

O-szint - átlevegőzött körülmények között képződött, le nem bomlott, vagy csak részlegesen lebomlott nagy mennyiségủ szerves anyagot (levél, fenyőtü, ág, gally stb.) tartalmazó felszíni szint (alomtakaró). Mind a szerves, mind az ásványi 
talajok felszínén, vagy mélyebb rétegekben eróziós folyamatok által eltemetve is előfordulhat. Az O-szint vízzel huzamos ideig sohasem telített. Az ásványi rész ebben a szintben jóval kevesebb, mint 50\%.

Ásványi talajszintek - A-szint - a felszínen, vagy az O-szint alatt fekvő humuszosodott, szerves anyagban gazdag, sötét színü talajszint. Morfológiai tulajdonságai és színe a humuszosodás hatására jelentősen eltér az alatta fekvő E-, B- vagy Cszintektől. Ha, szántóterület talaját vizsgáljuk, azt a szintet, ameddig a talajmüvelö eszközök forgató, lazító hatása érvényesül Ap-nek jelöljük.

Nem művelt terület talajának A-szintje alatt a humuszos felső szintet értjük. A finom rétegzettségüket megőrző fiatal folyóvízi vagy eolikus felszíni üledékek nem tekinthetőek A-szintnek, kivéve, ha szántottak.

Az eltemetett A-szinteket a betüjelük elé írt arab számokkal jelölik.

E-szint - a régebbi jelölés szerint az erdőtalajok, esetleg a szikes talajok esetében a felszíni humuszos A1-szint alatt, A2-vel jelöltük a kifakult, ún. kilúgzási szintet. A nemzetközi szakirodalmat követve ezt a szintet E-szintnek, vagyis eluviális, kilúgzási szintnek nevezzük. Az E-szint olyan felszín alatti ásványi talajszint, melyre az agyagásványokban, a vasban, az alumíniumban, vagy ezek kombinációiban történő elszegényedés jellemző. Az E-szint általában a felszín közelében, az O- vagy az A-szint alatt, és a felhalmozódási B-szint felett helyezkedik el. Szerkezete az alatta és felette elhelyezkedő talajszintekhez képest gyengébben fejlett, lazább. Textúrája durvább, színe pedig általában (de nem feltétlenül) fakóbb (nagyobb Munsell érték, vagy kisebb chroma érték jellemzi). Az E-szintekben a talajképző kőzet eredeti szerkezete már nem felismerhető.

B-szint - az A-, E-, O- vagy a H-szintek alatt fekvő felhalmozódási vagy átmeneti szint. A kilúgzással, sófelhalmozódással, illetve agyagelmozdulással jellemezhető talajokban itt halmozódnak fel a más szintekböl érkezett anyagok $\left(\mathrm{CaCO}_{3}\right.$, agyagásványok, stb.). Azokban a talajokban, amelyekre nem jellemzö az emlitett szelvényen belüli anyagmozgás, fokozatosan csökkenö humusztartalomú, átmeneti $B$-szintet találunk. A B-szint színe, szerkezete vagy a felhalmozódás jellege alapján tovább tagolható B1 és B2 alszintekre. A B-szint talajképződés hatására kialakult talajszerkezettel rendelkezik, a talajképző kőzet eredeti szerkezete benne már nem felismerhetö.

C-szint - A nem kemény vagy tömör talajképző kőzet jelölésére használjuk. A C-szintek nedvesen ásóval megbonthatóak, szárazon pedig vízbe helyezve 24 óra alatt szétiszapolódnak. Másodlagos sófelhalmozódáson, redukción, glejesedésen és málláson kívül talajképző folyamatok nem érintik.

\section{A talajrétegek (layers)}

A talajrétegek nem a talajképző tényezők és folyamatok hatására képződnek és különülnek el a talajszelvényben. Kialakulásukat különböző geológiai folyamatok és katasztrófák (pl. folyóvízi elöntés, eróziós szedimentáció, földcsuszamlás) okozzák, közöttük ún. „genetikai kapcsolat” nem áll fenn.

Jelölésük a genetikai talajszintekhez hasonlóan nyomtatott nagy betükkel történik, a következők szerint: 
R-réteg - az összefüggő ágyazati kemény kőzetet jelöli, melyet még nem alakítottak át a mállási, és más talajképző folyamatok. Ásóval nem megbonthatók és 24 óra áztatás után sem iszapolódnak szét.

L-réteg - a víz alatt felhalmozódott szerves és szervetlen anyagokból álló, ún. „limnikus” üledékeket jelöli. Az ún. limnikus anyagok kiválás, vagy vízi élőlények, pl. algák, diatómák tevékenysége által képződött, vagy víz alatti, ill. lebegő vízinövényekből származó, állati tevékenység hatására átalakult üledékek. L-réteg a koprogén vagy diatómaföld és a márga.

I-réteg - a fagyott, legalább $75 \%$ jeget (jéglencséket és jégéket) tartalmazó rétegek, melyekben a jég szerves, ill. ásványi rétegeket különít el a permafroszt területek talajaiban. A nemzetközi korreláció miatt a jelölést javasoljuk bevezetni, annak ellenére, hogy hazánkban ilyen talajok nem fordulnak elö.

W-réteg - a talajokban előforduló vízrétegek, ill. állandóan vagy napi ciklikussággal vízzel borított talajokat jelöli. Használata az ár-apály területek, a sekély (1 m-nél nem mélyebb) tavak alatti talajok, vagy az úszólápok esetében nyújt információt a víz jelenlétéröl.

\section{A talajszintek közötti átmenet jelölése}

Az ún. átmeneti talajszintek két típusa különíthető el. Első esetben az átmenetet képező talajszintek tulajdonságai az átmenetben együttesen jelennek meg, fokozatosan változnak, az átmenetben a két talajszint anyaga élesen nem különithetö el. Ekkor a szintek közötti átmenet jelölésére kettős betüjelzést használunk, mint az „AB”-, vagy a „BC”-szint esetében. Rendszerint az átmeneti szintben meghatározóbb talajszint jelét vesszük elöre.

Amennyiben azonban a két szint anyaga határozottan elkülönül az átmeneti rétegben, a szintek betüjele között „," jelet alkalmazunk, pl. Ap/B vagy C/D. Ebben az esetben is a nagyobb hányadban jelenlevő, meghatározóbb talajszint betüjele kerül elöre.

\section{A talajszintek további vertikális tagolódásának jelölése}

A genetikai talajszintek további vertikális tagolhatóságát, pl. szerkezet, szín vagy textúra alapján a szint betủjele után írt arab számokkal jelölik: A1, A2 vagy C1, C2. A számozás újraindul minden, új információt jelző újabb jelölés alkalmazásakor: Bt1 Bt2 Btk1 Btk2 (és nem: Bt1 Bt2 Btk3 Btk4).

A vertikális tagolódás folyamatos számozással történő jelzését a kőzettani különbségek nem befolyásolják: Bt1 Bt2 2Bt3 2Bt4 (és nem: Bt1 Bt2 2Bt1 2 Bt2).

\section{A talajszintek közötti genetikai és kőzettani különbségek jelölése}

A genetikailag és kőzettanilag (litológiai) különböző (eltemetett vagy többrétegü) talajokban az új talajanyag, vagy talajképző kőzet jelölésére a talajszint betüjele előtt arab számok használatosak, pl. 2B vagy $3 \mathrm{C}$. 
Az arab számjelölést az első genetikai és/vagy a kőzettani különbség (új talajanyag, vagy talajképző kőzet) megjelenésekor, az új talajanyag/talajképző kőzet betüjele elé helyezett 2 -es szám jelzi. A mélységgel folyamatosan megjelenő újabb rétegeket folyamatos sorszámozással jelöli: A B 2C 3C 4C 5C. Ha azonban kettő, vagy több talajszint ugyanazon a talajanyagon/talajképző kőzeten képződött összefüggő genetikai folyamattársulás hatására, ugyanaz az előtag szám: A B 2A 2B 2C.

\section{A másodlagos tulajdonságok jelölése a föbb szinteken belül}

A genetikai talajszintek további megkülönböztetésére és jellemzésére, ill. másodlagos tulajdonságok jelzésére a szintek betüjele után elhelyezett ún. indexek adnak lehetőséget.

A FAO kiadványa (FAO, 2006) 31 db másodlagos tulajdonságot jelző indexet határoz meg. Ezek közül három a víz alatt felhalmozódó üledékeket, talajokat jellemez (1. táblázat), öt a hazánk környezeti viszonyai között nem, vagy ritkán fordul elö (2. táblázat), de a nemzetközi kommunikáció miatt szükséges, 21 pedig a hazánkban gyakori elfordulású tulajdonságot jelöl (3. táblázat).

Egyszerre több index alkalmazása is megengedett, de általában kettőnél több használata nem gyakori. Ha, egyszerre több indexet alkalmazunk, a következőket jelöljük elsőként: r, s, t, u és w. A „t” index minden esetben elsőként jelölendő, pl. Btr, Btu; egyéb esetekben az ABC sorrendet követjük, pl. Cru.

Ha egynél több index alkalmazása szükséges (és a talajszint nem eltemetett), a következő indexek utolsóként jelölendők: c, f, g, m, v és x.

Ha eltemetett talajszintet jelölünk, a „b” utolsó indexként kerül felsorolásra. Talajvíz glejes, karbonátfelhamozódású B-szint jele például: Blk.

\section{1. táblázat}

Víz alatti üledékekben előforduló tulajdonságok

\begin{tabular}{|l|c|c|}
\hline Jelölés & Leírás & Előfordulási szintek \\
\hline $\mathrm{c}$ & koprogén anyag & L-szint \\
$\mathrm{d}$ & diatoma (kovaföld) & L-szint \\
$\mathrm{m}$ & márga & L-szint \\
\hline
\end{tabular}

2. táblázat

Hazai körülmények között nem, vagy ritkán előforduló tulajdonságok

\begin{tabular}{|l|c|c|}
\hline Jelölés & Leírás & Elöfordulási szintek \\
\hline $\mathrm{f}$ & fagyott talaj & ( $\mathrm{R}-$ nem lehet) \\
$\mathrm{q}$ & szilícium (kovasav) felhalmozódás & bármely \\
$\mathrm{v}$ & plintit jelenléte & bármely \\
$\mathrm{x}$ & fragipan & bármely \\
$@$ & krioturbáció (jég általi gyúrás) & bármely \\
\hline
\end{tabular}


3. táblázat

Hazai, gyakori előfordulású másodlagos tulajdonságok

\begin{tabular}{|c|c|c|}
\hline Jelölés & Leírás & Előfordulási szintek \\
\hline$a$ & erősen lebomlott szerves maradványok ${ }^{*}$ & H- és O-szintek \\
\hline $\mathrm{b}$ & eltemetett genetikai szint & bármely \\
\hline $\mathrm{c}$ & kiválások, nodusok $^{* *}$ & bármely \\
\hline $\mathrm{d}$ & kemény (nem cementált!), gyökerezést gátló réteg & ásványi szintek \\
\hline $\mathrm{e}$ & közepesen lebomlott szerves maradványok ${ }^{* * *}$ & H- és O-szintek \\
\hline $\mathrm{g}$ & pangóvíz okozta glejesség & bármely \\
\hline $\mathrm{h}$ & $\begin{array}{l}\text { másodlagos (vándorlás következtében történö) } \\
\text { szervesanyag felhalmozódás }\end{array}$ & ásványi szintek \\
\hline $\mathrm{ss}^{3}$ & csúszási tükör & ásványi szintek \\
\hline $\mathrm{i}$ & kis mértékben lebomlott szerves maradványok ${ }^{* * * *}$ & H- és O-szintek \\
\hline $\mathrm{j}$ & jarozitos foltosság & bármely \\
\hline $\mathrm{k}$ & másodlagos karbonát felhalmozódás & bármely \\
\hline 1 & talajvíz okozta glejesség & bármely \\
\hline $\mathrm{m}$ & cementált, kemény réteg & ásványi szintek \\
\hline $\mathrm{n}$ & kicserélhető nátrium felhalmozódás & bármely \\
\hline o & mállásból származó szeszkvioxid felhalmozódás & bármely \\
\hline $\mathrm{p}$ & szántás vagy egyéb müvelés, bolygatás & bármely \\
\hline $\mathrm{r}$ & erős redukció & bármely \\
\hline $\mathrm{s}$ & a kilúgzott szeszkvioxidok felhalmozódása & B-szint \\
\hline $\mathrm{t}$ & agyag-felhalmozódás & B-szint \\
\hline $\mathrm{u}$ & antropogén (,urbánus”) anyagok jelenléte & $\begin{array}{l}\text { H-, O-, A-, E-, B- és } \\
\text { C-szintek }\end{array}$ \\
\hline $\mathrm{w}$ & gyenge szín vagy szerkezet & B-szint \\
\hline $\mathrm{y}$ & gipsz felhalmozódás & bármely \\
\hline $\mathrm{z}$ & a gipsznél jobban oldódó sók felhalmozódása & bármely \\
\hline
\end{tabular}

Megjegyzés: * A szabad szemmel látható növényi maradványok aránya kevesebb, mint 1/6 térfogat \%; ** Változatos összetételü, kristályos vagy amorf szerkezetủ másodlagos ásványi kiválások; *** A szabad szemmel látható növényi maradványok aránya 1/6-2/3 térfogat $\%$; **** A szabad szemmel látható növényi maradványok aránya $2 / 3$ térfogat $\%$-nál több (SoIL SurVey Division StAFF, 1993; SCHOENEBERGER et al., 2012).

\section{Eredmények}

A FAO (2006) nemzetközi nomenklatúrájával harmonizált genetikai szintjelölések segítségével lehetővé válik a hazai talajtani adatbázisok harmonizálása, korrelációja. 
4. táblázat

A jelenlegi (SzABOLCS, 1966) és a javasolt fó genetikai szintjelölések

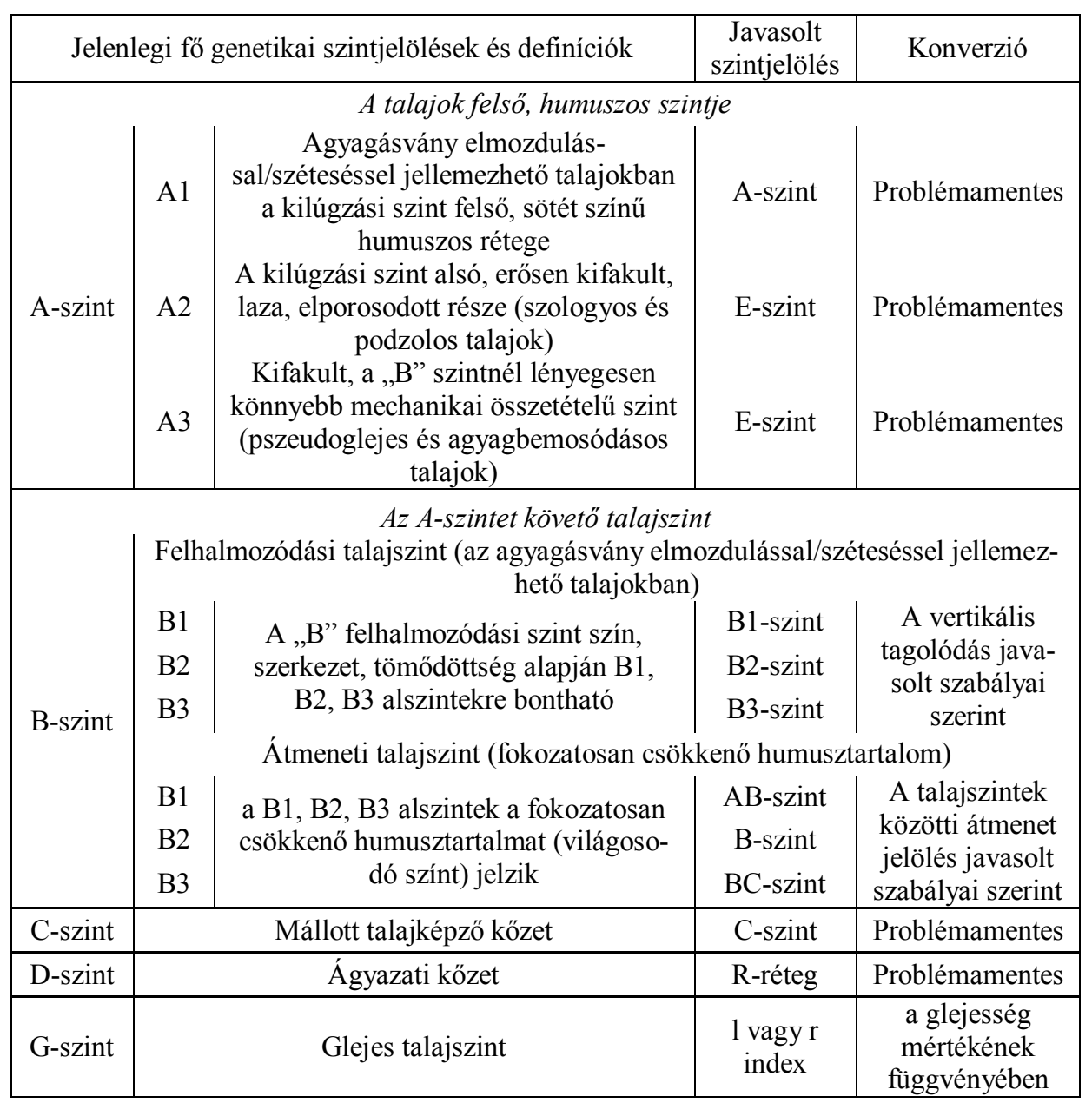

A 4. táblázat a jelenlegi (SzABOLCS, 1966), és a javasolt fő genetikai szintjelölések párhuzamos bemutatásával segíti a konverziót.

A jelenleg hivatalos nevezéktan (SZABOLCS, 1966) szerint a fö genetikai talajszint jelölések nem minden esetben követik a nemzetközileg elfogadott és alkalmazott normákat. A kilúgzási talajszintek hazánkban hagyományosan a talaj felső, humuszos „A” talajszintjének alszintjeiként határozták meg (A2, ill. A3). Ez a nevezéktani szabály azonban a többi fő genetikai talajszintnél alkalmazott hasonló jelöléssel (pl. B1, B2 vagy C1, C2) ellentétben nem a talajszint további alszintekre bontását, hanem másik talajképző folyamat hatására kialakult új talajszint jelenlétét jelöli. Így az alkalmazott nevezéktan azonos értelmezése, valamint az „A” talajszintek valódi alszintjeinek jelölése sem megvalósítható. 
A felhalmozódási-, ill. az átmeneti B-szintekben az azonos, B1 B2 B3 típusú jelölés szintén a nevezéktan azonos értelmezését és alkalmazását nehezíti, hiszen a felhalmozódási B-szintekben (szín, szerkezet, tömődöttség alapján meghatározott) vertikális tagolódásról, míg az átmeneti B-szintekben a humusztartalom csökkenésével jelzett fokozatos átmenet jelöléséről van szó.

A glejes tulajdonságokat jelző „G” talajszint helyett javasoljuk a nemzetközi nomenklatúrával harmonizált 1 vagy $\mathrm{r}$ index használatát - ezáltal lehetővé válik a glejességet mutató fő genetikai talajszint jelölése is a szelvényleírásakor.

A fö genetikai talajszintek további, másodlagos talajtulajdonságainak jellemzéséhez alkalmazott indexek közül 11 db-ot sorol fel SzABOLCS (1966) kiadványa. Az 5. táblázat ezen kiadvány betüjelöléseinek a javasolt index jelölésekkel való megfeleltetését mutatja be.

\section{5. táblázat}

A másodlagos talajtulajdonságokat jelölő jelenlegi indexek (SZABOLCS, 1966) javasolt jelölése és megfeleltetése

\begin{tabular}{|c|c|c|c|}
\hline \multicolumn{2}{|c|}{ Jelenleg alkalmazott betűindexek és definíciók } & \multirow{2}{*}{$\begin{array}{c}\begin{array}{c}\text { Javasolt } \\
\text { jelölés }\end{array} \\
\text { p index }\end{array}$} & \multirow{2}{*}{$\begin{array}{c}\text { Konverzió } \\
\text { Problémamentes }\end{array}$} \\
\hline $\mathrm{sz}$ & $\begin{array}{c}\text { szántott (csak „A” szinttel együtt } \\
\text { alkalmazható - Asz) }\end{array}$ & & \\
\hline oo & $\begin{array}{c}\text { alomtakaró - elbomlatlan növényi } \\
\text { maradványok (csak az „A” szinttel } \\
\text { együtt alkalmazható - Aoo) }\end{array}$ & Oi-szint & Problémamentes \\
\hline o & $\begin{array}{c}\text { alomtakaró - félig elbomlott növényi } \\
\text { maradványok (csak az „A” szinttel } \\
\text { együtt alkalmazható - Ao) }\end{array}$ & $\begin{array}{l}\text { Oe- vagy Oa- } \\
\text { szint }\end{array}$ & $\begin{array}{l}\text { A növényi maradvá- } \\
\text { nyok lebomlottsági } \\
\text { foka alapján }\end{array}$ \\
\hline $\mathrm{T}$ & $\begin{array}{l}\text { tőzegréteg (csak „A” szinttel együtt } \\
\left.\text { alkalmazható }-\mathrm{Ao}^{\mathrm{T}}\right)^{*}\end{array}$ & $\begin{array}{l}\text { Hi- vagy He- } \\
\text { szint }\end{array}$ & $\begin{array}{l}\text { A növényi maradvá- } \\
\text { nyok lebomlottsági } \\
\text { foka alapján }\end{array}$ \\
\hline $\mathrm{K}^{* *}$ & koturéteg & Ha szint & Problémamentes \\
\hline $\mathrm{k}$ & mészakkumlációs szintek & $\mathrm{k}$ index & Problémamentes \\
\hline $\operatorname{kav}^{* *}$ & kavics tartalmú réteg & $\mathrm{C} / \mathrm{R}$-szint & Problémamentes \\
\hline $\mathrm{G}$ & glejes rétegek & 1 index & Problémamentes \\
\hline $\mathrm{Gi}$ & gipszfelhalmozódási rétegek & $y$ index & Problémamentes \\
\hline PG & pszeudoglejes szintek & $\mathrm{g}$ index & Problémamentes \\
\hline szín & csak színben elütő B-szintek & $\mathrm{w}$ index & Problémamentes \\
\hline $\mathrm{E}$ & eltemetett szintek & $\mathrm{b}$ index & Problémamentes \\
\hline $\mathrm{Fe}$ & $\begin{array}{l}\text { vas, vagy vas-mangán kiválásokkal } \\
\text { igen erősen tarkított rétegek }\end{array}$ & $\begin{array}{l}1 \text { vagy g in- } \\
\text { dex, kemény } \\
\text { konkréciók } \\
\text { esetén c index }\end{array}$ & $\begin{array}{l}\text { A színmintázat és a } \\
\text { kiválások jellegének } \\
\text { függvényében }\end{array}$ \\
\hline $\mathrm{S}$ & $\begin{array}{l}\text { szemmel látható sókivirágzás, } \\
\text { sókérgek }\end{array}$ & $\mathrm{z}$ index & Problémamentes \\
\hline
\end{tabular}

Megjegyzés: *A jelölés a láptalajok talajszelvény leírásánál „B” talajszinteknél is megjelenik; ** A jelölés csak szelvényleírások példáiban jelenik meg 
A felsorolt indexek nem alkalmasak a hazánkban előforduló összes másodlagos talajtulajdonság jelzésére. A FAO (2006) útmutatója 31 db másodlagos talajtulajdonságot jelző indexet sorol fel, melyek közül 26 db fordulhat elő hazánk talajképződési viszonyai között.

Az indexek alkalmazása továbbá nem konzekvens sem az egyes hazai kiadványokon (SZABOLCS, 1966; JASSÓ, 1989) belül, ill. egyes esetekben az egyes kiadványok között sem (pl. kis és nagybetüvel jelzett indexek esetében), valamint használatuk nem széleskörüen elterjedt a hazai szakemberek között - így megújításuk indokolt.

Javaslatunk alapján az új szintjelölések és indexek alkalmazásával (6. táblázat) lehetővé válik a hazai talajtípusok szelvényfelépítésének részletesebb, a meghatározó talajképző folyamatokra és talajtulajdonságokra vonatkozó információt is tartalmazó, és a nemzetközi normákkal harmonizált leírása.

A jelenlegi, és a javasolt nevezéktan konverziója az esetek többségében problémamentes, a kérdéses esetekben a leíró (föképp morfológiai) jellegü talajadatok hiánya jelenthet problémát. Ezekben az esetekben javasoljuk szakértők bevonását a konverzió végrehajtásához, egyéb esetekben pedig automatizált algoritmusok (LÁNG, 2013) alkalmazását.

A 6. táblázat a talajtípusok átlagos szelvényfelépítésének jelenlegi (SzABOLCS, 1966), és javasolt jelölését mutatja be. A szelvényfelépítések a jelenleg érvényben levő útmutatóban sem minden esetben következetesek (a különböző fejezetekben különböző módon jelennek meg azonos talajtípus esetén), valamint a másodlagos tulajdonságok jelölésére használt indexek alkalmazása a leírásokban nem jellemző.

\section{6. táblázat}

Talajtípusaink átlagos szelvényfelépítésének jelenlegi (SzABOLCS, 1966) és javasolt jelölése

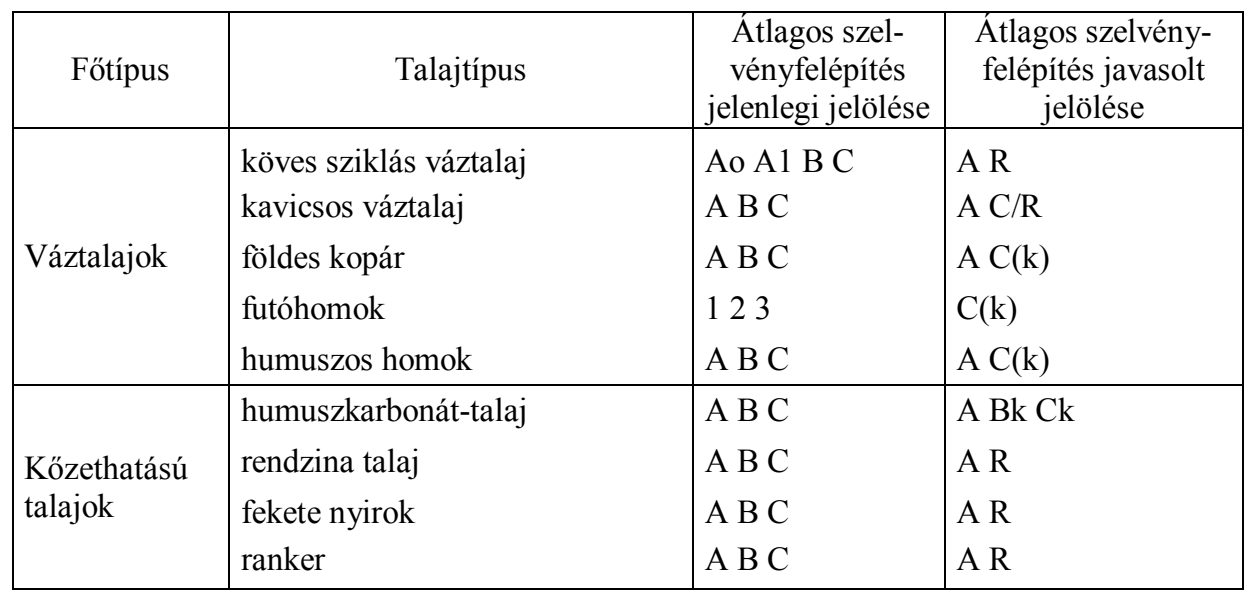




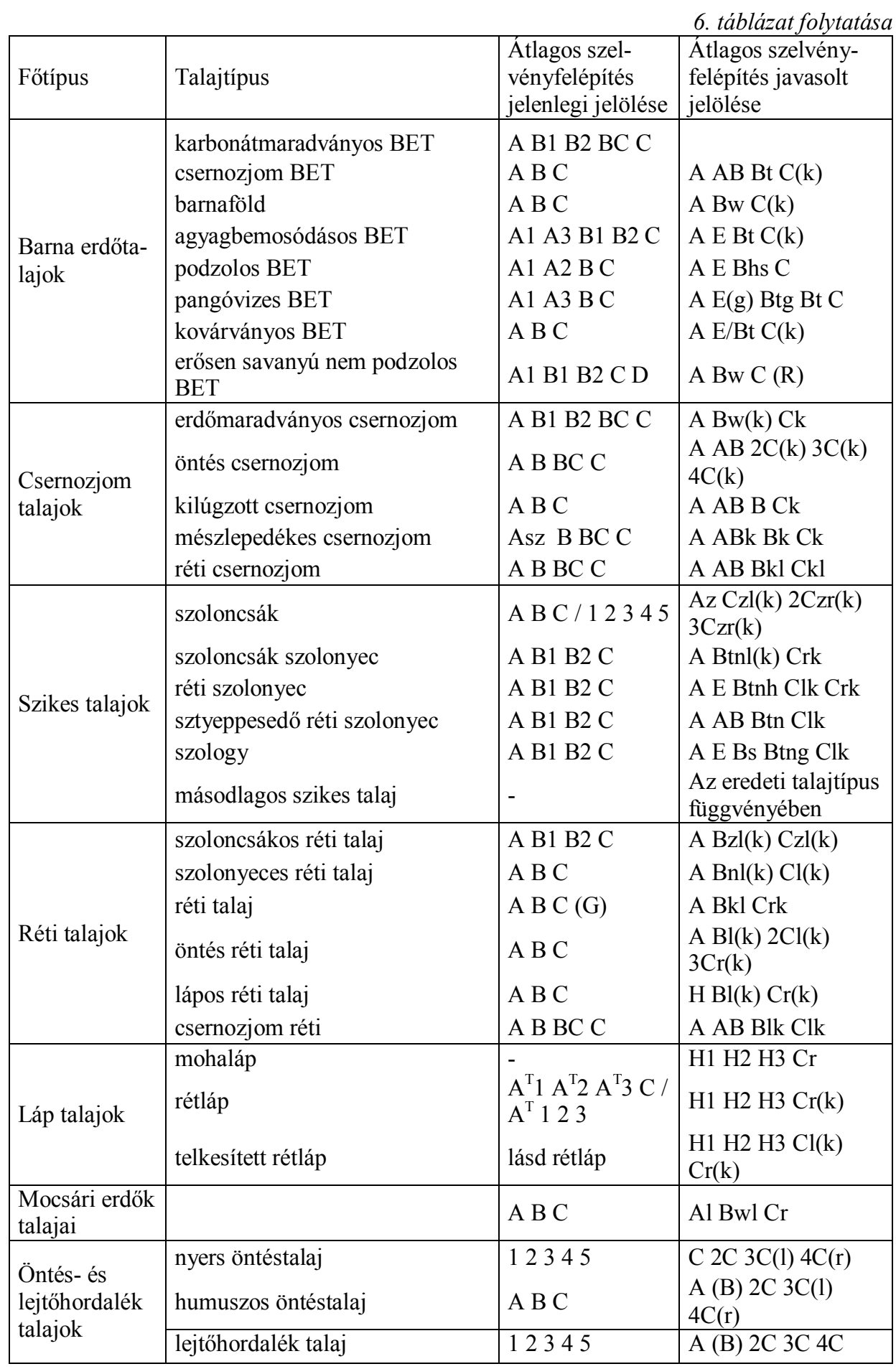




\section{Összefoglalás}

A talajképző tényezők és folyamatok együttes hatása alatt kialakult genetikai talajszintek, ill. geológiai-, vagy katasztrófa események hatására képződött talajrétegek jellemzése és azonos értelmezésü, a nemzetközi normákkal is harmonizált leírása nélkülözhetetlen információkat szolgáltat a talajtannal, talajadatokkal foglalkozó szakemberek számára.

A talajszelvények leírása többek között alapul szolgál a talajképződés folyamatának megértéséhez, a mintavételi mélységek meghatározáshoz és a talajok genetikai és diagnosztikai szemléleten alapuló osztályozásához.

Dolgozatunkban javaslatot teszünk a hazai genetikai talajszintek helyszíni leírásának a nemzetközi ajánlásokhoz alkalmazkodó, de szükség szerint a hazai körülményekre adaptált, ill. kiegészített megújítására, amely hozzájárul megújitás alatt álló hazai talajosztályozási rendszerünk fejlesztéséhez és lehetővé teszi a kor igényeinek megfelelő harmonizált talajadatbázisok építését.

A javaslat kidolgozásakor a FAO (2006) nemzetközileg elfogadott nevezéktant vettük alapul.

Munkánk során áttekintettük a jelenleg hivatalos hazai nevezéktant (SZABOLCS, 1966; JASSÓ, 1987, 1989) alkalmazása során fellépő problémákat és a jelenlegi, valamint a javasolt módszertan párhuzamos bemutatásával ismertettük a konverzió lehetőségeit.

Eredményeink alapján az új, javasolt módszertan alkalmazásával lehetővé válik a hazai talajtípusok szelvényfelépítésének részletesebb, a meghatározó talajképző folyamatokra és talajtulajdonságokra vonatkozó információt is tartalmazó és a nemzetközi normákkal harmonizált leírása, ill. a hazai talajadatbázisoknak a kor igényeinek megfelelő modernizálása.

Mivel a jelenlegi hivatalos útmutatók hozzáférhetősége csekély, a tankönyvek pedig csak átfogóan említik a talajszinteket, ezért „átállási” nehézségeket nem várunk.

A bemutatott munkát az Országos Tudományos Alap (OTKA T046513) és az Emberi Erőforrások Minisztériumának Kari Kiválósági Programja (7629-24/2013) támogatta.

Kulcsszavak: talajképződés, szelvényleírás, talajosztályozás, talajtípus

\section{Irodalom}

European Union, 2007. Directive 2007/2/EC of the European Parliament and of the Council of 14 March 2007 establishing an Infrastructure for Spatial Information in the European Community (INSPIRE). Official Journal of the European Union, L 108, 25 April 2007.

FAO, 2006. Guidelines for soil description. 4th edition. FAO, Rome. 
Hiederer, R., MichÉLi, E. \& Durrant T., 2011. Evaluation of BioSoil Demonstration Project - Soil Data Analysis. EUR 24729 EN. Luxembourg: Office for Official Publications of the European Communities. (ISBN:978-92-79-19320-0)

INSPIRE ThEMATIC WORKING GROUP SOIL, 2011. D2.8. III.3 INSPIRE Data Specification on SOIL - Draft Guidelines. Brussels.

JASSÓ F. (szerk.), 1987. Útmutató a nagyméretarányú országos talajtérképezés végrehajtásához. Melioráció - öntözés és tápanyaggazdálkodás.'87 melléklet. Agroinform. Budapest.

JASSÓ F. (szerk.), 1989. Útmutató a nagyméretarányú országos talajtérképezés végrehajtásához. Melioráció - öntözés és talajvédelem.' 88 melléklet. Agroinform. Budapest.

LÁNG, V., 2013. A hazai talajvédelmet és a nemzetközi megfeleltetést szolgáló adatrendszer fejlesztése. Ph.D értekezés. Szent István Egyetem, Környezettudományi Doktori Iskola.

Michéli, E., Büttner, S., Stefanovits, P., Szabóné Kele, G., Szegi, T. A., \& Tóth, G., 2009. A hazai talajosztályozás korszerüsítése és nemzetközi megfeleltetése c. OTKA-46513 pályázat zárójelentés. (http://real.mtak.hu/1468/1/46513_ZJ1.pdf)

Schoeneberger, P.J., Wysocki, D.A., Benham, E.C. \& Soll Survey StafF, 2012. Field book for describing and sampling soils, Version 3.0. Natural Resources Conservation Service, National Soil Survey Center. Lincoln, NE.

SoIL SuRveY Division StafF, 1993. Soil survey manual. Soil Conservation Service. U.S. Department of Agriculture Handbook 18.

StefanOVits P.,1972. Talajtan. Mezőgazda Kiadó. Budapest.

SzABOLCs I. (szerk.), 1966. A genetikus üzemi talajtérképezés módszerkönyve. OMMI. Budapest. 